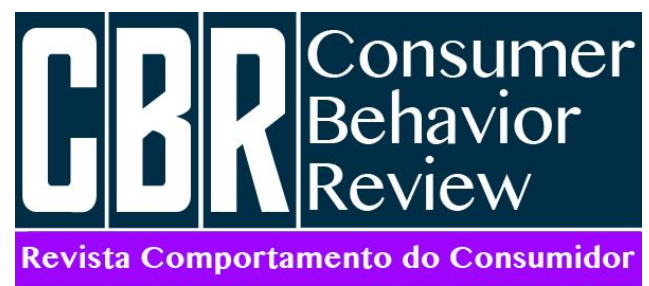

ISSN: 2526-7884

Editor: Prof. Dr. Marconi Freitas da Costa

E-mail: cbr@ufpe.br
Silva, L. E. N., Gomes Neto, M. B., Lessa, P. W. B., \& Grangeiro, R. R. (2021). Consumer's Choices in Critical Conditions: How Impulsive Buying Tendency Makes Consumers Seek Foreign Products. Consumer Behavior Review, 5(2), 158-169.

\title{
CONSUMER'S CHOICES IN CRITICAL CONDITIONS: HOW IMPULSIVE BUYING TENDENCY MAKES CONSUMERS SEEK FOREIGN PRODUCTS
}

Escolhas dos Consumidores em Condições Críticas: Como a Tendência de Compra por Impulsivo faz os Consumidores Procurarem Produtos Estrangeiros

Lucas Emmanuel Nascimento Silva ${ }^{1}$

ORCID: https://orcid.org/0000-0001-7767-1724

E-mail: lucasemmanuel1998@gmail.com

Manoel Bastos Gomes Neto ${ }^{1}$

ORCID: https://orcid.org/0000-0003-4400-5877

E-mail:neto26bastos@gmail.com

Patrick Wendell Barbosa ${ }^{1}$

ORCID: https://orcid.org/0000-0003-1892-2786

E-mail: patrickwbarbosa@gmail.com

Rebeca da Rocha Grangeiro ${ }^{1}$

ORCID: https://orcid.org/0000-0002-9292-2648

E-mail: rebeca.grangeiro@ufca.edu.br

\section{${ }^{1}$ Universidade Federal do Cariri, Juazeiro do Norte, Ceará, Brasil}

\begin{abstract}
The COVID-19 pandemic brought the attention of researchers to impulsive buying behaviors and the purchasing of local products, as they are fundamental for the economic recovery of the countries. Therefore, the purpose of this
\end{abstract}

\begin{abstract}
Resumo
A pandemia do COVID-19 chamou a atenção de pesquisas para comportamentos de compra impulsiva e de compra de produtos locais, por serem fundamentais para a recuperação econômica dos países. Portanto,
\end{abstract}


paper is to identify how the consumer's impulsive buying tendencies influence their choices for foreign products. We applied the Impulsive Buying Tendency Scale and the XScale of Xenocentrism to 300 young and adults. To analyze the data, we conducted a PLS-SEM analysis to test five hypotheses. Our results from the path analysis indicate that the affective aspects of impulsive buying tendency decrease the cognitive IBT $(\beta=-0.345)$, and increases the foreign admiration $(\beta=0,265)$ and domestic rejection $(\beta=0,226)$. Moreover, the cognitive aspect of IBT can also increase domestic rejection $(\beta=0,196)$. Our results follow the theory regarding xenocentrism, as consumers cognitively will consider foreign products as superior, thus rejecting the domestic ones. Furthermore, affective has also a significant impact on domestic rejection, which indicates that consumers may disregard local products because of individual frustrations. Overall, businesses need to take into account that to conquer those impulsive buyers, they need to show that they are more global and reinforce the product features. Research on the seek for foreign products and impulsive behavior will be fundamental as this purchasing can help the countries in the economic recovery after the COVID-19 crisis.

Keywords: Impulsive Consumption; Local Consumption; Foreign Products Consumption; Consumer Behavior. o objetivo deste artigo é identificar como as tendências de compra impulsiva do consumidor influenciam suas escolhas por produtos estrangeiros. Aplicamos a Impulsive Buying Tendency Scale e a X-Scale of Xenocentrism a 300 jovens e adultos. Para analisar os dados, conduzimos uma análise PLS-SEM para testar cinco hipóteses. Nossos resultados da análise de trilha indicam que os aspectos afetivos da tendência de compra impulsiva diminuem o IBT cognitivo $(\beta=-$ $0,345)$, e aumentam a admiração estrangeira $(\beta=0,265)$ e a rejeição doméstica $(\beta=0,226)$. Além disso, o aspecto cognitivo da IBT também pode aumentar a rejeição doméstica $(\beta=0,196)$. Nossos resultados seguem a teoria do xenocentrismo, pois os consumidores irão considerar cognitivamente os produtos estrangeiros como superiores, rejeitando os nacionais. Além disso, a dimensão afetiva também tem um impacto significativo na rejeição doméstica, o que indica que os consumidores podem desconsiderar os produtos locais por causa das frustrações individuais. De modo geral, as empresas precisam levar em consideração que, para conquistar esses compradores impulsivos, elas precisam mostrar que são globais e reforçar as características do produto. Pesquisas sobre a busca por produtos estrangeiros e comportamento impulsivo serão fundamentais, pois essas compras podem ajudar os países na recuperação econômica após a crise da COVID-19.

Palavras-chaves: Consumo Impulsivo; Consumo Local; Consumo de Produtos Estrangeiros; Comportamento do Consumidor.

\section{INTRODUCTION}

The COVID-19 pandemic was firstly declared in March 2020 and caught the researcher's attention that sought to investigate the challenges that this health crisis brought to consumption. The decision-making process in this scenario can be more irrational (He \& Harris, 2020). Therefore, consumers adopt impulsive buying behaviors in this crisis and thus started to buy more products without planning in fear of them being scarce soon (Kirk \& Rifkin, 2020).

This increase in the consumption of basic products, the changes in the production process, and the isolation policies brought a disruption of the global supply chain that can impact a specific subject of consumer ethical decision, the purchase of domestic or foreign products (He \& Harris, 2020). The consumers were encouraged to buy local-manufactured products and the pandemic lead to some 
geopolitical tensions regarding distribution (He \& Harris, 2020), especially concerning health equipment. However, research investigating impulsive purchasing and buying of foreign products is scarce.

The concern of buying local products is especially relevant because of the economic problems brought by this crisis, thus encouraging the purchase of local products is fundamental for the survival of the small business and overall economic recovery. Therefore, there is a need to investigate how does the seek for foreign products will be affected by the impulsive consumption behaviors that consumers adopted.

The discussion on the consumption of a foreign country was explored by the literature of ethnocentrism in consumer behavior (cf. Ma, Abdeljelil \& Hu, 2019). As opposite to consumer ethnocentrism, there are discussions of xenocentrism as a phenomenon where "consumers' devaluing of native cultural aspects and overrating of foreign cultural values" (Rojas-Méndez \& Chapa, 2019, p. $355)$.

The result of xenocentrism is people seeking foreign products even if they are more expensive and of lower quality (Balabanis \& Diamantopoulos, 2016). Xenocentrism can be seen more frequently in underdeveloped nations, thus, the economic, social, political, and cultural aspects can shape the way consumers see the foreign brands (Rojas-Méndez \& Chapa, 2019).

Studies on consumer xenocentrism have been overlooking its concept (eg. Varela, Gaur, Bathula \& Diaz, 2015), measurement possibilities (eg. Rojas-Méndez \& Chapa, 2019), and why consumers seek foreign products (eg. Balabanis \& Diamantopoulos, 2016). However, little attention has been put into how other consumer concepts increase this xenocentric behavior. For instance, Karunaratne \& Wanninayake (2019) found that ethnocentric consumers buy with a pre-planned purchasing decision, thus reducing impulsive buying tendency. However, there is still a need to understand if xenocentric consumers, as opposed to ethnocentric, have a tendency to impulsive buying. The literature has yet to address those issues.

In the COVID-19 pandemic, there was an increase in panic behavior and impulsive buying as consumers were seeking basic products scared of they becoming scarce (Kirk \& Rifkin, 2020), and also consumers came across the decisions of buying national or foreign products. In light of this, the purpose of this paper is to identify how the consumer's impulsive buying tendencies influence their choices for foreign products. To achieve this goal, we conducted a quantitative study with 300 youth and adults using the Impulsive Buying Tendency (Mittal, Chawla \& Sondhi, 2016) to measure consumer's tendency of impulse buying and the X-Scale (Rojas-Méndez \& Chapa, 2019) to measure consumer xenocentrism. To analyze the data and test our hypotheses, we used Partial Least Square Structural Equation Modeling (PLS-SEM), a useful analysis when theory is less established, thus important in this exploratory research.

\section{IMPULSIVE BUYING TENDENCY}

As much as economic reasons are important for making purchases, they are not the only one, since consumers purchase goods or services for various reasons, such as "fun, fantasy, and social or emotional gratification" (Hausman, 2000, p. 413). Also, impulse buying can elevate the customer's emotional well-being, since, when entering a store, "they may become emotionally uplifted and spend more than intended" (Park, Kim, \& Forney, 2006, p. 442).

Furthermore, impulse buying is the result of the relationship between "various internal and external stimuli" (Muruganantham \& Bhakat, 2013). Mohan, Sivakumaran, and Sharma (2013) stated that impulse buying can be generated according to the environment, that is, an external stimulus can cause a consumer to increase his desire to purchase a good or service.

Regarding the power of influence in the context of impulse buying, Kacen and Lee (2002) argued that culture is capable of affecting the impulsiveness of buying and consumer buying behavior. In addition to the culture, the visibility of the product can influence the acquisition of the good or service, especially when there are signs of promotional prices (Mehta \& Chugan, 2013). Besides that, interaction with sellers is very important to motivate impulse buying behavior (Park \& Lennon, 2006). Thus, it is clear that the influences around the consumer can stimulate impulsive buying behavior. 
Impulse buying definition goes beyond an acquisition without planning, being conceptualized as a sudden and immediate purchase, with no intention of pre-purchase and with little reflection on the rational consequences of the long-term purchase (Beatty \& Ferrel, 1998). The literature on impulsive buying has focused on the antecedents that lead consumers to buy without planning, they are the product features, situational factors, cultural factors, and individual factors (cf. Rook, 1987; Dias, Santos, Martins \& Isabella, 2014).

Recently, investigating a sample of Portuguese respondents, Lins et al., (2020) sought to identify what lead people to impulsive buying. By reviewing the literature, the authors highlight the economic factors, product-related factors, situational factors, internal factors. Furthermore, with a qualitative research, they found that the primary reseasons are internal factors (Emotional, Volition, Physiologic, and Cognitive) and monetary value (Lins et al., 2020).

The discussions led to an understanding of impulsive buying tendency as a personality trait and that has a great influence on consumer impulsive buying behavior (Mittal, Chawla, \& Shandi, 2016). IBT can be explained as a spontaneous and sudden urge to make purchases and act on those urges without reflecting on them (Beatty \& Ferrell, 1998). The IBT thus helps to understand the antecedents of impulsive buying and the behaviors (Mittal, Chawla, \& Shandi, 2016).

\section{XENOCENTRISM}

Consumer behavior has adopted the discussions of sociology and anthropology regarding ethnocentrism to understand how this phenomenon affects consumer choices and thus impacts their behavior (Hsu \& Nien, 2008). However, an "opposite" concept has also been discussed in the literature, the consumer xenocentrism. The term xenocentrism was first discussed in 1951 by Kent \& Burnight and refers to 'consumers' devaluing of native cultural aspects and overrating of foreign cultural values" (Rojas-Méndez \& Chapa, 2019, p. 355). Mueller, Damacena \& Torres (2020) argue that although ethnocentrism has been extensively investigated in consumer research, xenocentrism is somewhat neglected. Furthermore, there is a lack of research that could provide a sufficient and indepth theoretical analysis of the phenomenon (Camacho et al., 2020).

Xenocentrism describes people that are centered in foreign groups and can have high dislikes for their own culture (Kent \& Burnight, 1951). It needs to be reinforced that the xenocentrism phenomenon has a subjective nature and implies a biased view (Kent \& Burnight, 1951). The relevance of studying xenocentrism is especially important for national enterprises that need to investigate why consumers seek foreign products and this information is even more relevant for developing countries (Camacho et al., 2020).

Xenocentrism is the opposite of Ethnocentrism, those who see fault in their society and those who see their society as superior to the others (Kent \& Burnight, 1951). Consumer xenocentrics thus, "tend to undervalue the image of their home country and display negative attitudes towards domestic brands" (Diamantopoulos et al., 2019, p. 7). Young people could show more xenocentric tendencies, as especially the college students, have greater contact with other cultures, and with globalization, this contact with other cultures was increased even further (Kent \& Burnight, 1951; Camacho et al., 2020)

In a more recent perspective, Mueller, Wang, Liu \& Cui (2015) found that xenocentrism was very common in China, and consumers have sought more western products, especially the new emerging wealthy class, young consumers, and the local elite. When there are too many xenocentric people, the national esteem is at risk, thus increasing the chance of ethnocentric behavior (Mueller et al., 2015), therefore, it should be kept at a minimum (Kent \& Burnight, 1951).

People can show xenocentric behavior for a lot of reasons, mainly individual frustration and inferior social position (Kent \& Burnight, 1951). New research has found that xenocentrism can have a positive direct effect to purchase intention, perceived product quality, and product attitudes (Camacho et al., 2020). People with personal frustration can project it to their society as a whole and individuals in an inferior social position can think of the people in better positions as superior (Kent \& Burnight, 1951). 


\section{Hypothesis}

Based on the available literature and in this paper aims to identify how the consumer's impulsive buying tendencies influence their choices for foreign products we developed five hypotheses to be tested by the structural model.

Firstly, the affective dimension of consumers' impulsive buy tendency (IBT) is connected to emotions, being those negative or positive (Mittal, Chawla, \& Shandi, 2016) and the cognitive dimension refers to reflect and analyze the benefits of the purchase. Therefore, we propose the first hypothesis that H1: Affective IBT decreases Cognitive IBT. An increase in the affective domain of impulsive buying tendency will decrease the cognitive aspect regarding the reflections that the consumers do when buying.

Xenocentrism implies a biased view and can be caused by individual frustration (Kent \& Burnight, 1951), thus, is highly impacted by the affective domain. Therefore, we present the following hypothesis: H2: Affective IBT increases Foreign Admiration, and H3: Affective IBT increases Domestic Rejection.

Consumers with xenocentric behavior believe their culture is faulty and the other is superior (Kent \& Burnight, 1951). The authors also reinforce how young people are more likely to show this behavior because they were more exposed to other cultures. Furthermore, Camacho et all. (2020) found that the product attitudes as the evaluation of the good or bad nature of the product can be a mediator of the purchase intentions in the context of xenocentrism. Thus, cognition and the learning of other cultures is an important predictor of consumer xenocentrism. Therefore, the last hypothesis is H4: Cognitive IBT increases Foreign Admiration, and H5: Cognitive IBT increases Domestic Rejection. The structural model and a summarization of the hypothesis that is going to be investigated are presented in figure 1.

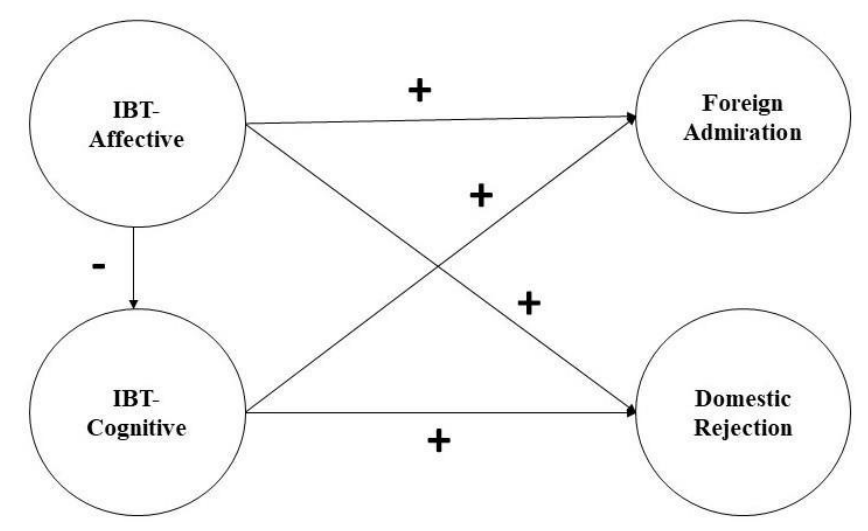

Figure 1. Hypothesis and Structural Model

\section{METHOD}

Aiming to identify how the consumer's impulsive buying tendencies influence their choices for foreign products, we conducted a quantitative research using partial least square - structural equation modeling (PLS-SEM) to identify the relationships in the model and to assess our hypothesis. The choice of PLS-SEM over CB-SME (Covariance - Based - Structural Equation Modeling) was due to weak development of the literature about impulsive buying tendency and xenocentrism, and our sample size is small (Hair et al., 2016).

\section{Measurement Instruments}

To measure the domain of consumer's impulsive buying tendency and consumer xenocentrism, we chose the Impulsive Buying Tendency (Mittal, Chawla, \& Sondhi, 2016) to measure consumer's tendency of impulse buying and the X-Scale (Rojas-Méndez \& Chapa, 2019) to measure consumer xenocentrism. 
The impulsive buying scale has 11 items and is divided into two dimensions (Affective- IBT, and Cognitive-IBT). The scale was previously validated in India. The authors argue that although impulsive buying research is concerned with developing countries, the majority of the measurement instruments were developed in the USA and Europe (Mittal, Chawla, \& Sondhi, 2016). Furthermore, using a qualitative exploratory study, the authors were able to build a valid and reliable instrument to measure impulsive buying tendencies.

The X-Scale, the xenocentrism scale is composed of 10 items and is also divided into two dimensions (Foreign Admiration and Domestic Rejection). The authors analyze consumer xenocentrism through "positive attitudes toward foreign products; and negative attitudes toward domestic products" (Rojas-Méndez \& Chapa, 2019, p. 11). The statistical analysis also confirms a valid and reliable instrument to measure consumer xenocentrism.

\section{Adaptation of the Measurement Instruments}

The first step in the application of the scale was the translation of the items to Portuguese. This was initially made by each of the researches of this paper and after that, we all confer to compare the translations and improve the items to the application in Brazil.

After the translation of the instrument, we proceed to an analysis of specialists in the field of consumer research. The reviewers had access to all the items and they would indicate which dimension they believe the item was from and how appropriate the writing was. This step helps us to refine the scale and see if some items had any problem regarding comprehension and therefore, we could assess construct validity and face validity.

Finally, after the translation and the evaluation of specialists, we developed the questionnaire. The questionnaire had the scale questions in the format of a Likert 10-point scale and they were mixed to avoid response bias and also sociodemographic questions to analyze the profile of our sample. At the beginning of the questionnaire, the consumer could read a message indicating the purpose of the study, the author's contact, and questions to assure them that the answers were anonymous and answers would be used only for academic purposes and they could, in the end, indicate if would like to comply or not with the survey.

\section{Data Collection and Sample}

Our sampling process was non-statistical through convenience sampling, which is useful for exploratory research. The data was collected through an online survey applied in Brazil from April to May 2020. The online address of the survey was shared on WhatsApp, Facebook, Instagram, and Telegram by the authors to increase our reach.

A total of 314 questionnaires were applied. However, after cleaning procedures to identify the existence of missing values and outliers with missing value levels above $5 \%$ and the exclusion of respondents under 18 years of age. 14 questionnaires were excluded, leaving a total of 300 responses. We did not identify missing values during the exploratory data analysis process. Of all the consumers that answered the questionnaire, 23,3\% ( $=97)$ were cis male, $63 \%(\mathrm{~N}=189)$ cis female, and 2,7\% $(\mathrm{N}=8)$ nonbinary. Six answers were invalid. Regarding the age, the age mean of the respondents was 25,99 years old. With the median of 22 years and 21 was the most common age of the respondents.

They live mostly on Ceará $(78 \%, \mathrm{~N}=234)$ and Pernambuco $(5,7 \%, \mathrm{~N}=17)$. Concerning the marital status, $78,3 \%(\mathrm{~N}=235)$ were single, $18,3 \%$ married $(\mathrm{N}=55)$ and $3,3 \%(\mathrm{~N}=10)$, divorced. Finally, with regards to education, they have mostly completed high school $(37,3 \%, \mathrm{~N}=112), 33 \%(\mathrm{~N}=99)$ went to college and $16,7 \%(\mathrm{~N}=50)$ have a Master's or Ph.D. degree.

\section{Data Analysis}

The purpose of the analysis was to identify the path coefficients on how impulsive buying tendency impacts the choice of foreign products (xenocentrism), therefore, the use of PLS is more appropriated since our interest resides in the causal relationships. All the procedures were performed on the free software SmartPLS 3 and were carried out with the support of specialized literature (Bejamin \& Gaskin, 2014; Ringle et al., 2014; Hair et al., 2014; Hair, 2016). As the scales were already 
validated, we proceed directly to the confirmatory factor analysis. We assess the convergent and discriminant validity and the reliability analyzed by chrombach's alpha and composite reliability.

\section{RESULTS}

\section{Descriptive Data Analysis}

To assess the structural model, we followed the steps recommended by Hair et al. (2016). The first stage was the assessment of reflective measurement models (Internal Consistency, Convergent Validity, and Discriminant Validity). Since we had no formative measurement model, we proceed to the evaluation of the structural model (Coefficients of Determination, Predictive Relevance, Size and Significance of Path Coefficients, $\mathrm{f}^{2}$ effect sizes, and $\mathrm{q}^{2}$ effect sizes). Figure 1 shows our first measurement model.

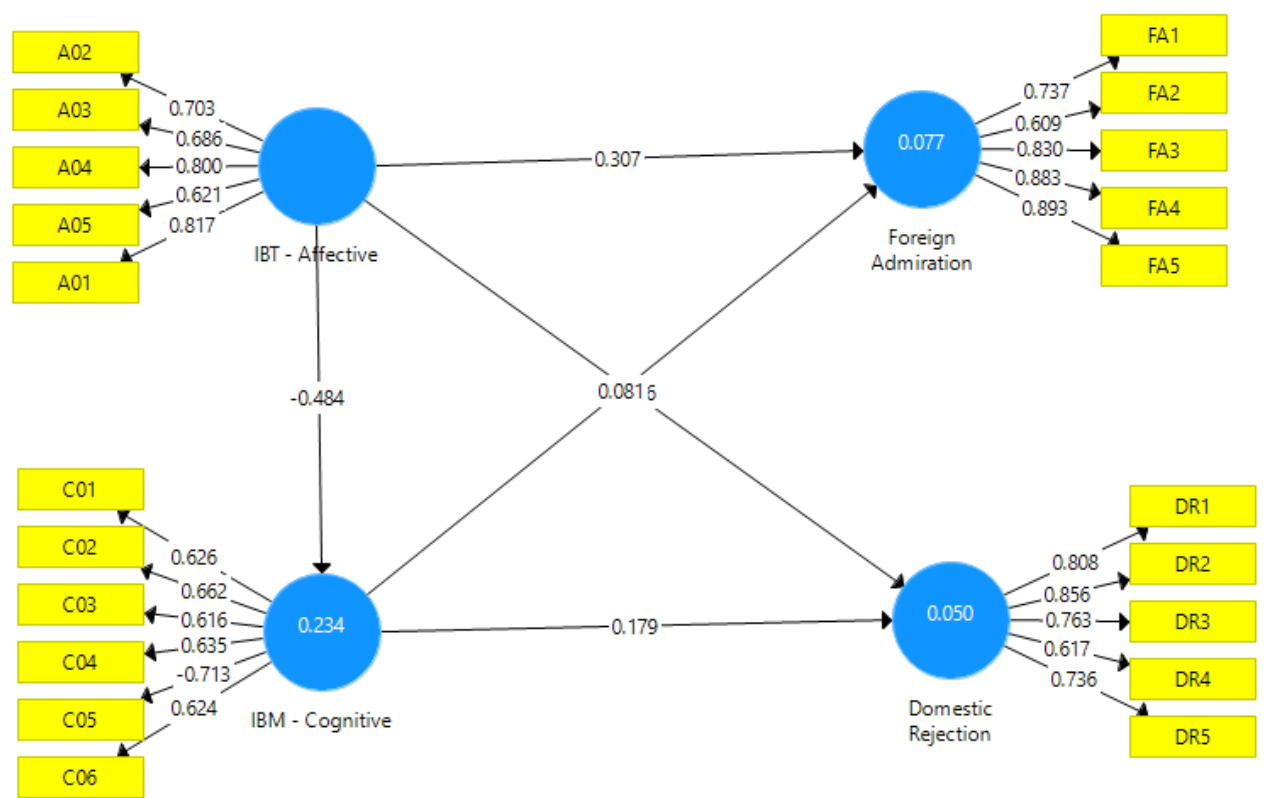

Figure 1. Initial Structural Model

Analyzing the factor loadings, we notice quickly that items 5 (C05) and 6 (C06) were causing problems and reducing the overall convergent validity of the model. To correct this issue, we exclude the two items and proceed to analyze the convergent validity. Table 1 presents the results.

Table 1

Convergent Validity

\begin{tabular}{|c|c|c|c|c|c|}
\hline Construct & Items & AVE & CR & CA & $\mathbf{R}^{2}$ \\
\hline IBT- Affective & $\begin{array}{l}\mathrm{A} 01 \\
\mathrm{~A} 02 \\
\mathrm{~A} 03 \\
\mathrm{~A} 04 \\
\mathrm{~A} 05\end{array}$ & .532 & .848 & 0.777 & - \\
\hline $\begin{array}{c}\text { IBT- } \\
\text { Cognitive }\end{array}$ & $\begin{array}{l}\mathrm{C} 01 \\
\mathrm{C} 02 \\
\mathrm{C} 03 \\
\mathrm{C} 04 \\
\end{array}$ & .561 & .835 & 0.735 & 0.119 \\
\hline
\end{tabular}




\begin{tabular}{cccccc}
\hline & FA1 & & & \\
Foreign & FA2 & .635 & .896 & 0.851 & 0.070 \\
Admiration & FA3 & & & \\
& FA4 & & & \\
& FA5 & & & \\
\hline & DR1 & .872 & 0.579 & 0.059 \\
Domestic & DR2 & .579 & & \\
Rejection & DR3 & & & \\
& DR4 & & & \\
& DR5 & & & \\
\hline
\end{tabular}

As shown in Table 2, we achieve discriminant validity and thus proceed to the analysis of the structural model.

Table 2

Discriminant Validity

\begin{tabular}{c|c|c|c|c|}
\hline & D.R & F.A & IBT-C & IBT-A \\
\hline D.R & $\mathbf{0 . 7 6 1}$ & & & \\
F.A & 0.698 & $\mathbf{0 . 7 9 7}$ & & \\
IBT-C & 0.119 & 0.022 & $\mathbf{0 . 7 4 9}$ & \\
IBT-A & 0.158 & 0.263 & -0.345 & $\mathbf{0 . 7 3 0}$ \\
\hline
\end{tabular}

After the assessment of validity and reliability, we furthered the data analysis process by bootstrapping the model to identify whether the t-values were significant to test the hypotheses. The subsamples of the bootstrapping were 500 and the correlation is significant at a t-value level of $>1.96$. Table 3 summarizes the results of the bootstrapping.

Table 3

Bootstrapping

\begin{tabular}{c|c|c|c}
\hline Hypothesis & Std. Error & T-Value & P-Value \\
\hline H1 & 0.052 & 6.684 & 0.000 \\
\hline H2 & 0.061 & 5.003 & 0.000 \\
\hline H & 0.062 & 3.633 & 0.000 \\
\hline H4 & 0.071 & 1.808 & 0.071 \\
\hline H5 & 0.061 & 3.227 & 0.001 \\
\hline
\end{tabular}

The next step to assess the adequacy of the model was to identify the predicted validity $\left(Q^{2}\right)$ and effect size $\left(\mathrm{f}^{2}\right)$. Predictive validity refers to how the construct behaves how it is expected from it and effect size is how each construct is useful to the model (Ringle et al., 2014). Table 4 presents the results.

Table 4

Predictive Validly and Effect Size

\begin{tabular}{c|c|c}
\hline & CV RED $\left(\mathbf{Q}^{\mathbf{2}}\right)$ & CV COM (f $\left.\mathbf{f}^{\mathbf{2}}\right)$ \\
\hline Affective IBI & & 0.374 \\
\hline Cognitive IBI & 0.062 & 0.275 \\
\hline Foreign Admiration & 0.040 & 0.446 \\
\hline Domestic Rejection & 0.028 & 0.374 \\
\hline
\end{tabular}

The results indicate a good predictive Validly and effect Size as the $\mathrm{Q}^{2}$ should be $>0$ and $\mathrm{f}^{2}$ values of $0,02,0,15$, and 0,35 are considered, respectively small, medium, and large (Hair et al., 2014). After the assessment of the quality of the structural model, we proceed to the analysis of the path coefficients (table 5). 
Table 5

Path Coefficients

\begin{tabular}{c|c} 
Causal Relationship & Path Coefficients \\
\hline H1: Affective IBT decreases Cognitive IBT. & $-0,345$ \\
\hline H2: Affective IBT increase Foreign Admiration & 0,264 \\
\hline H3: Affective IBT increases Domestic Rejection. & 0,226 \\
\hline H5: Cognitive IBT increases Domestic Rejection & 0,196 \\
\hline
\end{tabular}

\section{DISCUSSIONS}

We confirmed that affective impulsive buying tendency will decrease cognitive impulsive buying tendency (Path Coefficient $=-0,345$ ). Consumers that buy in impulse are buying for an emotional aspect (Mittal, Chawla, \& Shandi, 2016), thus reducing the reflections of the purchase, such as if it is necessary or if the product it is worth. Future research needs to investigate how consumer's that plan the purchases and think previously about the product still end up impulsive buying. Research in consumer psychology using neurologic methods would further this phenomenon comprehension.

The relationship between the affective IBT dimension and the foreign admiration and domestic rejection was also confirmed (Path Coefficient $=0,264$ and 0,226 respectively). Xenocentric people believe the other culture and products are good and theirs are faulty (Kent \& Burnight, 1951; RojasMéndez \& Chapa, 2019). Furthermore, this phenomenon can be caused by individual frustration and interior position (Kent \& Burnight, 1951), thus the affective dimension has a significant impact on xenocentrism and can increase the seek for foreign products. It is interesting to note that even though the inferior position has been pointed out as a cause for xenocentric behavior (Kent \& Burnight, 1951), in China, Mueller et al., (2015) found that the local elite and a new emerging wealthy class sought more foreign products. Therefore, there is a need to investigate further the role of wealth in xenocentrism. As people with more money have more opportunity to buy impulsively, they could also demonstrate a bigger level of xenocentrism. However, further research needs to address these issues.

Finally, H4: Cognitive IBT increases Foreign Admiration was rejected, as the T-value and pvalue were insignificant. This result could indicate that when it comes to the role of cognition, people do not admire foreign products. This could be explained by a belief that national products and culture are better or even the same as the foreign. Future research needs to address if consumers feel ashamed to admire other cultures or if their notion of patriotism does not include admiring the outside culture. Also, the research could investigate how is the purchase process of the consumers that plan before buying, and if in this process, the role of the nationality of this product is considered.

Interestingly, we could confirm the hypothesis that cognitive IBT increases domestic rejection (Path Coefficient $=0,196$ ). Even though consumers might not admire foreign products, there is still an increase in domestic rejection when you consider the cognitive dimension of impulsive buying. This could be explained by Kent \& Burnight (1951) who argue that people could dislike their culture just for the sake of doing so, without preferring a foreign one. This implies some interesting issues that need to be further addressed. Future studies could investigate why people would hate their culture just for doing so. The discussions of status consumption and symbolic consumption could investigate the implications that lay with this behavior and how are the consumers seen in society. Brazil is a very applicable field to discuss those issues, as there is the famous expression "Complexo de Vira-Lata" which refers to Brazilians lack self-esteem and seeks a foreign culture.

\section{CONCLUSIONS}

The purpose of this paper was to identify how the consumer's impulsive buying tendencies influence their choices for foreign products. We conducted PLS-SEM to analyze the five proposed hypotheses based on the literature to expand the body of knowledge we have available reading consumer xenocentrism and impulsive buying tendency. This paper brings some significant implications that need to be addressed both academically and in the business sphere. Firstly, this paper presents a contribution regarding the analysis of impulsive buying tendency and xenocentrism. To the extent of our knowledge, no other study has done so. Previous research has investigated 
ethnocentrism and impulsive consumption (see. Karunaratne \& Wanninayake, 2019), but not xenocentrism.

Nonetheless, the fact that the research took place mainly in those states can even be relevant as they are often marginalized in the media, thus could increase xenocentrism. What we saw, in reality, was the mean of Foreign Admiration and Domestic Rejection, which can also be explained by some response bias, as consumers will seek to respond in the way that they believe is more socially accessible, however, we believe the online survey reduce this bias as consumers would respond alone without the interference of the research.

Furthermore, those implications are also very important to businesses. Companies need to understand that emotional aspects will increase consumer xenocentrism, thus negative feelings could increase even further. Advertising should emphasize a happy approach and make the consumer happy to be a part of the culture. Impulsive buyers have a tendency to seek foreign products, therefore, having a significant impact on local businesses. Those businesses need to reinforce where they are from to maintain their identity but also to show some "globalness" to attract consumers. Notwithstanding, these local businesses that are built upon local culture could explore further their product's features and how it is good to conquer these customers, as product attitudes are fundamental to purchase intentions (Camacho et al., 2020).

Finally, we are living in a different context and consumer behavior is changing quickly and we need to investigate even more. With the COVID-19 pandemic, people are more concerned with how the brand is responding to the crisis and concerned with corporate social responsibility policies (He \& Harris, 2020). Thus, consumers are looking more at how foreign and national companies are acting and since they are consuming local products to help these local businesses, our understating of xenocentrism shortly can be different and the reasons for it could challenge our concepts wellestablished in the literature.

However, people's xenocentric behavior can also be increased in the COVID-19 pandemic. The main reason could be individual frustration (Kent \& Burnight, 1951) that one may have with the country's actions towards this health crisis. People may believe other countries are better because they deal better with the pandemic. Therefore, the relationship between public policies and consumer behavior is even more important today. These are challenging times but an existing opportunity for consumer researchers to investigate new consumption patterns and to help in developing theory and policies to improve consumer's wellbeing.

Despite the relevant contributions of this paper, we still need to highlight the limitation of the research. Firstly, the sample size was small and non-probabilistic, thus generalizations should be made with caution. Furthermore, the majority of our sample is from the Northeast of Brazil, therefore some response bias may be found.

\section{References}

Balabanis, G., \& Diamantopoulos, A. (2016). Consumer xenocentrism as determinant of foreign product preference: A system justification perspective. Journal of International Marketing, 24(3), 58-77. DOI: https://doi.org/10.1509/jim.15.0138

Beatty, S. E., \& Ferrell, M. E. (1998). Impulse buying: Modeling its precursors. Journal of retailing, 74(2), 169-191. DOI: https://doi.org/10.1016/S0022-4359(99)80092-X

Camacho, L. J., Salazar-Concha, C., \& Ramírez-Correa, P. (2020). The Influence of Xenocentrism on Purchase Intentions of the Consumer: The Mediating Role of Product Attitudes. Sustainability, 12(4), 1647. DOI: https://doi.org/10.3390/su12041647

Diamantopoulos, A., Davydova, O., \& Arslanagic-Kalajdzic, M. (2019). Modeling the role of consumer xenocentrism in impacting preferences for domestic and foreign brands: A mediation analysis.Journal of Business Research, 104, 587-596. DOI: https://doi.org/10.1016/j.jbusres.2018.12.007 
Dias, S. E. F., Maria dos Santos, R., Martins, V., \&amp; Isabella, G. (2014). Efeitos das estratégias de marketing de compras coletivas sobre o comportamento impulsivo. Revista Brasileira de Marketing, 13(3), 138-151. DOI: https://doi.org/ 10.5585/remark.v13i3.2646

F. Hair Jr, J., Sarstedt, M., Hopkins, L., \& G. Kuppelwieser, V. (2014). Partial least squares structural equation modeling (PLS-SEM) An emerging tool in business research. European Business Review, 26(2), 106-121. DOI: https://doi.org/10.1108/EBR-10-2013-0128

Hair Jr, J. F., Hult, G. T. M., Ringle, C., \& Sarstedt, M. (2016). A primer on partial least squares structural equation modeling (PLS-SEM). Sage publications.

Hausman, A. (2000). A multi-method investigation of consumer motivations in impulse buying behavior. Journal of consumer marketing, 17(5), 403-426. DOI: https://doi.org/10.1108/07363760010341045

He, H., \& Harris, L. (2020). The Impact of Covid-19 Pandemic on Corporate Social Responsibility and Marketing Philosophy. Journal of Business Research, 116, 176-182. DOI: https://doi.org/10.1016/j.jbusres.2020.05.030

Hsu, J. L., \& Nien, H. P. (2008). Who are ethnocentric? Examining consumer ethnocentrism in Chinese societies. Journal of Consumer Behaviour: An International Research Review, 7(6), 436-447. DOI: https://doi.org/10.1002/cb.262

Kacen, J. J., \& Lee, J. A. (2002). The influence of culture on consumer impulsive buying behavior. Journal of consumer psychology, 12(2), 163-176. DOI: https://doi.org/10.1207/S15327663JCP1202_08

Karunaratne, L. G. A. S., \& Wanninayake, W. M. C. B. (2019). Consumer Ethnocentrism and Its Influence on Impulsive Buying Behaviour in Sri Lankan Milk Powder Market: The Moderation Effect by the Consumer Impulsiveness Traits. Kelaniya Journal of Management, 7(2), $1 . \quad$ DOI: http://doi.org/10.4038/kjm.v7i2.7574

Kent, D. P., \& Burnight, R. G. (1951). Group centrism in complex societies. American Journal of Sociology, 57(3), 256-259. Retrieved April 5, 2021, from http://www.jstor.org/stable/2771646

Kirk, C. P., \& Rifkin, L. S. (2020). I'll Trade You Diamonds for Toilet Paper: Consumer Reacting, Coping and Adapting Behaviors in the COVID-19 Pandemic. Journal of Business Research, 117, 124-131. DOI: https://doi.org/10.1016/j.jbusres.2020.05.028

Lins, S., Marques, M., \& Aquino, S. D. (2021). "What drives one to buy on impulse?" A qualitative study with a Portuguese sample. Consumer Behavior Review, 5(1), 17-30.

Ma, Q., Abdeljelil, H., \& Hu, L. (2019). The Influence of the consumer ethnocentrism and cultural familiarity on brand preference: Evidence of Event-Related Potential (ERP). Frontiers in Human Neuroscience, 13, 220. DOI: https://doi.org/10.3389/fnhum.2019.00220

Mehta, N., \& Chugan, P. K. (2013). The impact of visual merchandising on impulse buying behavior of consumer: A case from Central Mall of Ahmedabad India. Universal Journal of Management, 1(2), 76-8. DOI: https://doi.org/10.13189/ujm.2013.010206

Mittal, S., Chawla, D., \& Sondhi, N. (2016). Impulse buying tendencies among Indian consumers: Scale development and validation. Journal of Indian Business Research, 8(3), 205-226. DOI: https://doi.org/10.1108/JIBR-09-2015-0101

Mohan, G., Sivakumaran, B., \& Sharma, P. (2013). Impact of store environment on impulse buying behavior. European Journal of marketing, 47(10), 1711-1732. DOI: https://doi.org/10.1108/EJM-03-2011-0110

Mueller, A., Damacena, C., \& Torres, C. V. (2020). The Xenocentrism scale in Brazil: validation with wine consumers. International Journal of Wine Business Research, 32(3), 423-440. DOI: https://doi.org/10.1108/IJWBR-05-2019-0035

Mueller, R. D., Wang, G. X., Liu, G., \& Cui, C. C. (2015). Consumer xenocentrism in China: an exploratory study. Asia Pacific Journal of Marketing and Logistics, 28(1), 73-91. DOI: https://doi.org/10.1108/APJML-11-2014-0158

Muruganantham, G., \& Bhakat, R. S. (2013). A review of impulse buying behavior. International Journal of Marketing Studies, 5(3), 149. DOI: https://doi.org/ 10.5539/ijms.v5n3p149

Park, E. J., Kim, E. Y., \& Forney, J. C. (2006). A structural model of fashion-oriented impulse buying behavior. Journal of Fashion Marketing and Management: An International Journal, 10(4), 433446. DOI: https://doi.org/10.1108/13612020610701965 
Park, J., \& Lennon, S. J. (2006). Psychological and environmental antecedents of impulse buying tendency in the multichannel shopping context. Journal of consumer Marketing, 23(2), 56-66. DOI: https://doi.org/10.1108/07363760610654998

Ringle, C. M., Da Silva, D., \& Bido, D. D. S. (2014). Modelagem de equações estruturais com utilização do SmartPLS. Revista Brasileira de Marketing, 13(2), 56-73. DOI: https://doi.org/10.5585/remark.v13i2.2717

Rojas-Méndez, J. I., \& Chapa, S. (2019). X-Scale: A new scale to measure consumer xenocentrism. Marketing Intelligence \& Planning, 38(3), 354-368. DOI: https://doi.org/10.1108/MIP-01-2019-0062

Rook, D. W. (1987). The buying impulse. Journal of consumer research, 14(2), 189-199. DOI: https://doi.org/10.1086/209105

Varela, J. C. S., Gaur, S. S., Bathula, H., \& Diaz, C. V. (2015). Conceptualising the influence of the cultural orientation of latin americans on consumers' choice of US brands. European Business Review, 27(5), 477-494. DOI: https://doi.org/10.1108/EBR-03-2013-0061 